\title{
Antibody Binding to Fas Ligand Attenuates Inflammatory Cell Infiltration and Cytokine Secretion, Leading to Reduction of Myocardial Infarct Areas and Reperfusion Injury
}

\author{
Hirokazu Shiraishi, Tetsuya Toyozaki, Yoshiaki Tsukamoto, Toshihiro Saito, \\ Yoshiaki Masuda, Kenzo Hiroshima, Hidemi Ohwada, Nobuyuki Kobayashi, and \\ Michiaki Hiroe
}

Department of Cardiovascular Science and Medicine (HS, YT, TS, YM) and Department of Basic Pathology (TT, KH, HO), Graduate School of Medicine, Chiba University, Chiba; Department of Clinical Pharmaceutics (NK), Faculty of Pharmaceutics Science, Nagasaki University, Nagasaki; and Nephrology and Cardiology Division (MH), International Medical Center of Japan, Tokyo, Japan

SUMMARY: Fas ligand (FasL) induces apoptotic cell death when bound to Fas antigen. The engagement of FasL has anti-inflammatory effects through the prevention of cell proliferation and cytokine secretion. However, the role of FasL in myocardial ischemia/reperfusion (Ml/R) injury is unclear. We examined the expression of FasL mRNA in the myocardium of MI/R rats by ligating the left coronary artery for 30 minutes and allowing reperfusion to occur for $0,1,3$, and 24 hours. The expression of FasL mRNA was enhanced 1 hour after reperfusion, and enhanced levels were consistently seen after 24 hours of reperfusion. FasL immunostaining was observed on neutrophils, macrophages, T cells, and vascular endothelial cells. We then assessed the potential role of FasL in the cell proliferation and cytokine production seen in MI/R injury after 24 hours of reperfusion. Rats were divided into three groups; Group A, without treatment; Group B, treated with nonspecific rabbit IgG; and Group C, treated with anti-FasL antibody. Anti-FasL antibody or rabbit IgG were administered intravenously before coronary artery occlusion. In Group $\mathrm{C}$, interleukin- $1 \beta$ and interleukin-2 mRNA levels were decreased, and neutrophil and T cell accumulation was attenuated. The infarct area determined by triphenyltetrazolium chloride staining was significantly smaller in Group C $(18 \pm 4 \%)$ than in Group A $(34 \pm 2 \%)$ or Group B $(33 \pm 4 \%)(p<0.0001)$. However, there was no significant difference in the prevalence of terminal deoxynucleotidyltransferase-mediated dUTP-biotin nick end-labeling-positive cardiomyocytes among the three groups. These findings suggest that the cardioprotective effect of anti-FasL antibody is due to its anti-inflammatory action, rather than antiapoptotic action. The Fas/FasL system may be involved in the development of MI/R injury. (Lab Invest 2002, 82:1121-1129).

$E$ arly coronary artery reperfusion plays a key role in reducing myocardial tissue injury associated with acute myocardial infarction. Nevertheless, reperfusion itself can cause damage to the myocardium, termed myocardial ischemia/reperfusion (Ml/R) injury (Braunwald and Kloner, 1985). In MI/R injury, several kinds of inflammatory cells, including neutrophils, macrophages, and $\mathrm{T}$ cells, accumulate in the reperfused tissue (Birdsall et al, 1997; Dreyer et al, 1991; Ono et al, 1999). Accumulating neutrophils may contribute to production of myocardial damage by releasing oxygen

DOI: 10.1097/01.LAB.0000029148.88524.CE

Received October 31, 2001.

This study was supported by Grant-in-Aid for Scientific Research from the Ministry of Education, Science, and Culture of Japan (076770765 and 08670828), and a Research Grant for Diseases from the Ministry of Health and Welfare of Japan.

Address reprint requests to: Dr. Michiaki Hiroe, Nephrology and Cardiology Division, International Medical Center of Japan, 1-21-1, Toyama, Shinjuku-ku, Tokyo, 162-8655, Japan.E-mail:mhiroe@imcj.hosp.go.jp free radicals, proteases, and leukotrienes (Mehta et al, 1988). Macrophages elaborate proinflammatory cytokines, such as interleukin (IL)- $1 \beta$, TNF- $\alpha$, and IL-6, which mediate the acute inflammatory response and subsequent remodeling after $\mathrm{MI} / \mathrm{R}$ injury (Finkel et al, 1992; Herskowitz et al, 1995; Yue et al, 1998).

Fas ligand (FasL, CD95L) is a 40-kd type II membrane protein member of the TNF/nerve growth factor family (Suda et al, 1993) that induces apoptosis by binding to its membrane receptor Fas (Nagata and Golstein, 1995). In Langendorff perfusion, the Fas/ FasL system contributes to cell death in cardiac cells in response to Ml/R injury (Jeremias et al, 2000). However, recent reports indicate that FasL has other important functions as well as this well-known apoptosis-promoting activity. First, FasL itself has chemotactic activity and triggers inflammation. Enforced FasL expression was found to facilitate rejection by triggering a neutrophil-mediated inflammatory response. This response was observed in a variety of cell lines and tissues, namely, islets (Allison et al, 1997; Kang et al, 1997b), myoblasts (Kang et al, 1997a), and 
tumor cells (Arai et al, 1997; Miwa et al, 1998; Seino et al, 1997). Furthermore, a soluble type of FasL (sFasL) was a potent chemoattractant for human neutrophils (Ottonello et al, 1999). These reports suggest that FasL has strong proinflammatory properties. Second, FasL itself transduces signals independently of Fas signals. FasL engagement by a recombinant form of sFas, FasFc, stopped $\mathrm{CD}^{+} \mathrm{T}$ cell proliferation and cytokine secretion. When engaged by FasFc, CD4 ${ }^{+} \mathrm{T}$ cells undergo cell cycle arrest and cell death (Desbarats et al, 1998). It is known that neutrophils, macrophages, and T cells express FasL (Kiener et al, 1997; Liles et al, 1996; Nagata, 1994). In this study, we analyzed the expression of FasL in MI/R and examined whether anti-FasL antibody can prevent inflammation and reduce the infarct size in a rat model of MI/R.

\section{Results}

\section{Expression of FasL in Ischemic Reperfused Myocardium}

Figure 1A shows representative results of RT-PCR of FasL mRNA. The expression of FasL mRNA in the reperfused myocardium was shown to increase 1 hour after reperfusion, and markedly increased levels were consistently seen after 24 hours of reperfusion (Fig. 1B). Figure 2 shows immunohistochemical staining for

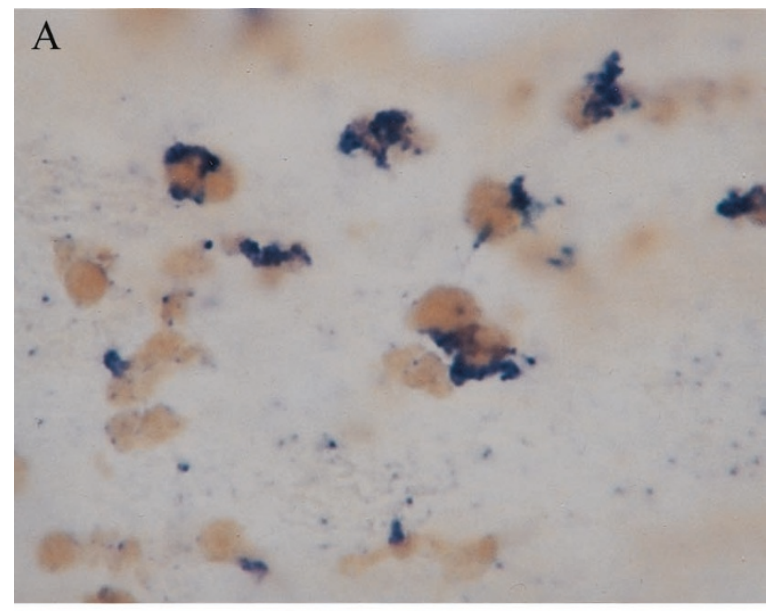

B

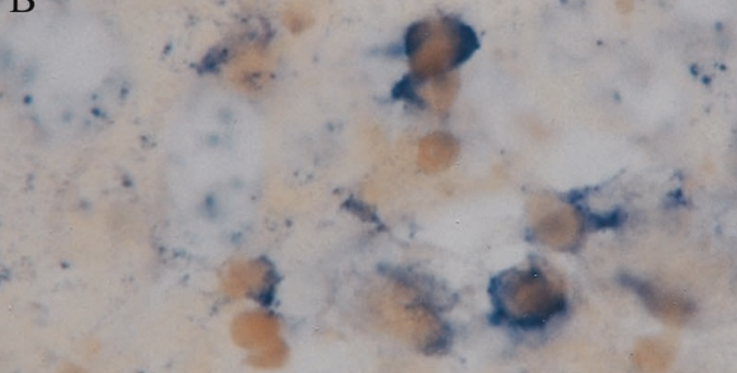

A

Fas L

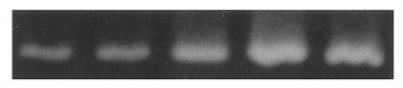

GAPDH

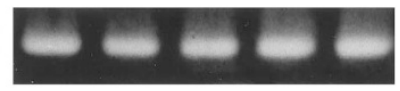

$\begin{array}{llllll}C & 0 & 1 & 3 & 24 & \text { Hours }\end{array}$

B

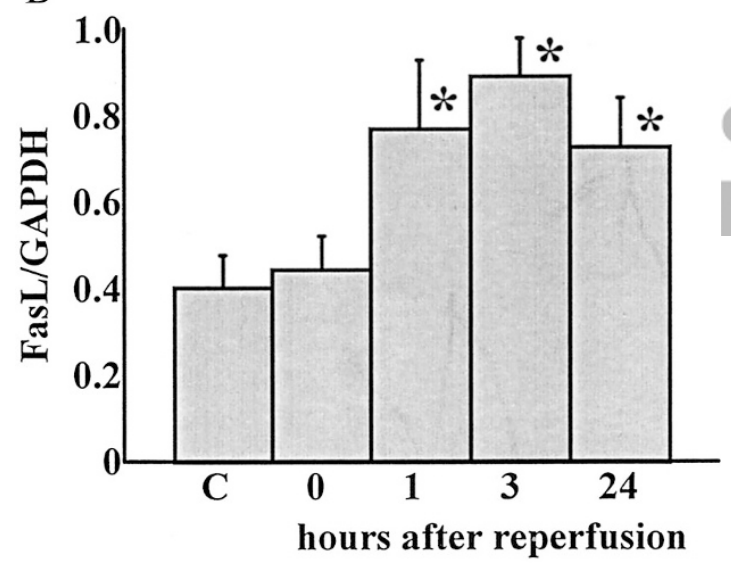

Figure 1.

Fas ligand (FasL) mRNA expression in myocardial ischemia/reperfusion (MI/R) rats. A, Time course of FasL mRNA expression in the myocardium of rats subjected to 30 minutes of left coronary artery occlusion and killed $0,1,3,24$ hours after reperfusion. Control $(C)$ represents FasL mRNA expression in the heart of a normal rat. B, Graphic representation of the time course of FasL mRNA expression normalized to the level of glyceraldehyde-3-phosphate dehydrogenase (GAPDH). The ratio of FasL/GAPDH in MI/R rats $(n=5)$ was higher than in control rats 1,3 , and 24 hours after reperfusion. ${ }^{*} p<0.0001$ compared with control rats $(n=5)$.

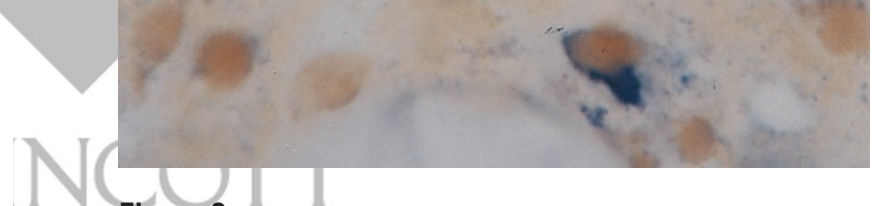

Figure 2.

Immunohistochemical staining for FasL, ED1, and OX19 in MI/R rats. FasL was visualized with diaminobenzidine (brown) and ED1 and OX19 with Fast Blue (blue). A, Double staining using anti-FasL antibody and OX19 in reperfused rats (original magnification, $\times 640$ ). B, Double staining using anti-FasL antibody and ED1 in reperfused rats (original magnification, $\times 640$ ).

FasL, ED1, and OX19. FasL immunoreactivity was observed in neutrophils, ED1-positive inflammatory macrophages, ED2-positive resident macrophages, OX6-positive dendritic cells, OX19-positive T cells, and vascular endothelial cells (data not shown). The major populations of FasL-positive cells were neutrophils, ED1-positive macrophages, OX19-positive cells, and vascular endothelial cells 24 hours after reperfusion.

\section{Regulation of Cytokine Expression after Administration of Anti-FasL Antibody}

Figure 3 shows representative results of RT-PCR of $\mathrm{IL}-1 \beta$, IL-2, IL-6, TNF- $\alpha$, and interferon (IFN)- $\gamma$ mRNA and graphical representations of the relative level of mRNA expression of each, normalized to the level of glyceraldehyde-3-phosphate dehydrogenase (GAPDH) mRNA. In the hearts of control rats, IL-1 $\beta$, TNF- $\alpha$, and IFN- $\gamma$ mRNA were weakly expressed, whereas IL-2 and IL-6 mRNA were not detected. Significant elevation of each cytokine was found during the 24-hour period after reperfusion, and administration of anti-FasL antibody 
A

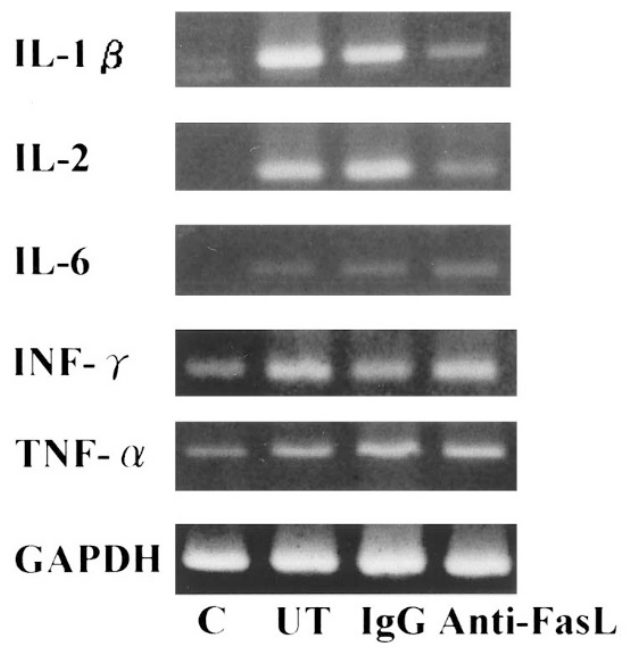

B
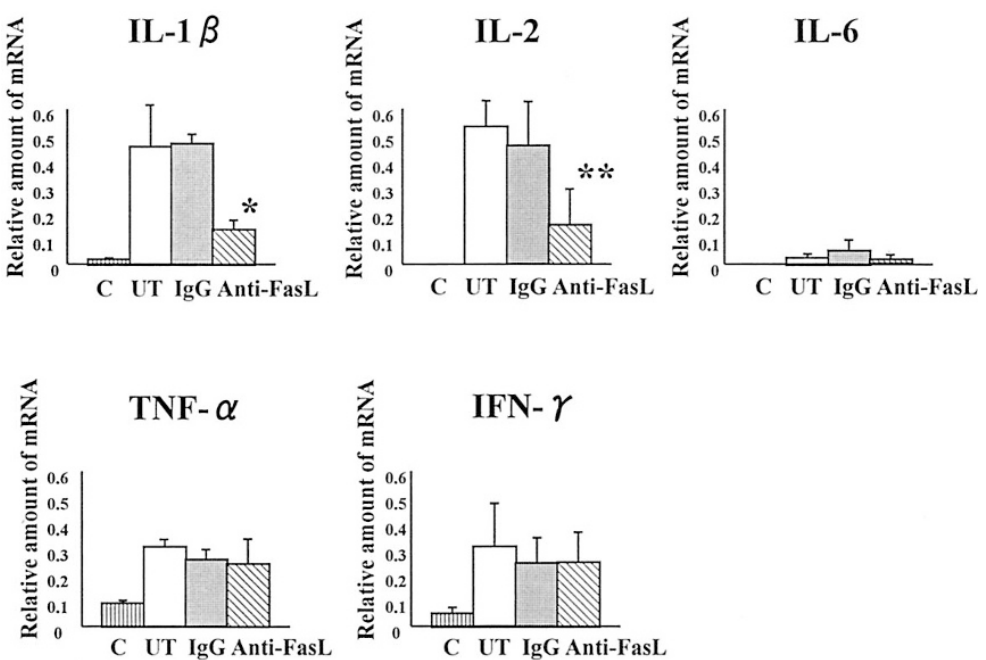

Figure 3.

Effect of anti-FasL antibody on IL-1 $\beta$, IL-2, IL-6, IFN- $\gamma$, and TNF- $\alpha$ mRNA expression. A, Cytokine mRNA expression from the myocardium 24 hours after reperfusion of untreated rats $(U T)(n=5)$, rats treated with nonspecific rabbit $\lg G(\lg G)(n=5)$, and rats treated with anti-FasL antibody $($ Anti-FasL) $(n=5)$. Control $(C)$ corresponds to levels of cytokine mRNA in the hearts of normal rats. B, Relative level of IL-1 $\beta$, IL-2, IL-6, IFN- $\gamma$, and TNF- $\alpha$ mRNA (cytokine/GAPDH). * $p<0.05$, ${ }^{* *} p<0.01$ versus untreated group and group treated with rabbit $\operatorname{lgG}$

resulted in a marked decrease of mRNA expression only in IL-1 $\beta(p<0.01)$ and IL-2 $(p<0.05)$.

\section{Effect of Anti-FasL Antibody on Neutrophils, OX19-, and ED1-Positive Cell Infiltration}

Rats were divided into three groups: Group A, without treatment; Group B, treated with nonspecific rabbit lgG; and Group C, treated with anti-FasL antibody. Examples of the histologic appearance of the ischemia/reperfusion (I/R) myocardium stained with naphthol AS-D chloroacetate esterase (Leider stain) from Group A and Group C are shown in Figure 4. Dense neutrophilic infiltrates were present in the I/R myocardium of rats from Group A. In contrast, the neutrophilic infiltrates in the myocardium were markedly reduced in rats from Group $C$. The number of neutrophils, OX19-, or ED1-positive cells, which were also predominantly immunoreactive for FasL, was calculated in each group. The numbers of neutrophils in Group A, Group
B, and Group C were $677 \pm 32$ cells $/ \mathrm{mm}^{2}, 680 \pm 55$ cells $/ \mathrm{mm}^{2}$, and $397 \pm 25$ cells $/ \mathrm{mm}^{2}$, respectively. Group C had significantly less neutrophilic infiltration than Group $A$ and Group B $(p<0.0001)$. The numbers of OX19-positive cells in Group A, Group B, and Group C were $947 \pm 94$ cells $/ \mathrm{mm}^{2}, 931 \pm 66 \mathrm{cells} / \mathrm{mm}^{2}$, and $755 \pm 28 \mathrm{cells} / \mathrm{mm}^{2}$, respectively. The number of OX19-positive cells in Group C was smaller than in Group A and Group B $(p<0.05)$. However, the number of ED1-positive cells was similar among the three groups (Group A, $674 \pm 51$ cells $/ \mathrm{mm}^{2}$; Group B, $666 \pm 38$ cells $/ \mathrm{mm}^{2}$; Group C, $679 \pm 76$ cells/ $\mathrm{mm}^{2}$ ) (Fig. 5).

\section{Apoptotic Index}

Terminal deoxynucleotidyltransferase-mediated dUTPbiotin Nick End-labeling (TUNEL)-positive nuclei were detected in scattered myocytes in reperfused area lesions (Fig. 6). The apoptotic index in Group A, Group B, 

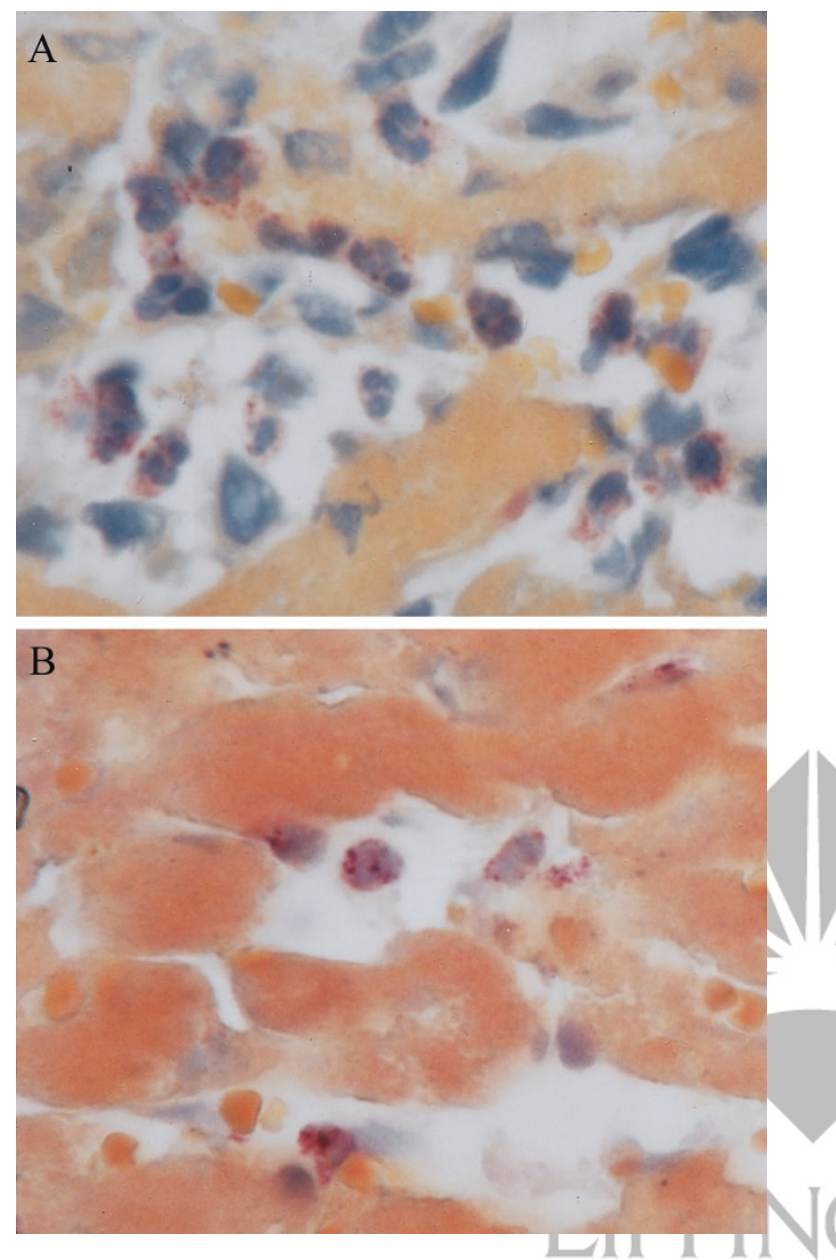

Figure 4.

Infiltrating neutrophils stained with naphthol-ASD chloroācetate esterase 24 hours after reperfusion. Representative sections of myocardium of $A$, an untreated rat (original magnification, $\times 640$ ) and $B$, a rat treated with anti-FasL antibody (original magnification, $\times 640$ ).

and Group C was $6.7 \pm 1.7 \%, 6.8 \pm 1.0 \%$, and $7.2 \pm$ $1.8 \%$, respectively. There was no significant difference among the three groups (Fig. 7).

\section{Effect of Anti-FasL Antibody on Myocardial Infarct Size}

Figure 8 shows representative heart sections of rats from each group. Anti-FasL antibody reduced the infarct size. The ratios of infarct area to left ventricular area in Group A, Group B, and Group C were $34 \pm$ $2 \%, 33 \pm 4 \%$, and $18 \pm 4 \%$, respectively. The ratio in Group $C$ was significantly smaller than in Group A and Group B $(p<0.0001)$ (Fig. 9).

\section{Discussion}

In this report, we clearly demonstrated a cardioprotective action of intravenous administration of antiFasL antibody resulting from attenuation of neutrophil infiltration and cytokine secretion in a rat model of $\mathrm{MI} / \mathrm{R}$ injury. It has been shown that inflammatory cells, including neutrophils, macrophages, $\mathrm{T}$ cells, and proinflammatory cytokines are important regulators in reperfusion injury (Birdsall et al, 1997; Dreyer et al, 1991; Finkel et al, 1992; Herskowitz et al, 1995; Mehta et al, 1988; Ono et al, 1999; Zwacka et al, 1997). Neutrophils cause myocardial tissue injury through mechanical obstruction of capillary vessels, production of vasoactive substances, or release of cytotoxic agents (Mehta et al, 1988). Macrophages and T cells also contribute to the pathogenesis of reperfusion injury (Birdsall et al, 1997; Ono et al, 1999; Zwacka et al, 1997). An important role of these cells is secretion of proinflammatory cytokines such as IL- $1 \beta$, TNF- $\alpha$, IL-6, IL-2, and IFN- $\gamma$ (Herskowitz et al, 1995; Nathan, 1987; Salgame et al, 1991). Proinflammatory cytokines produced by inflammatory cells promote further inflammatory cell infiltration and influence acute tissue injury and later tissue remodeling or progression of heart failure (Finkel et al, 1992; Herskowitz et al, 1995; Yue et al, 1998).

In this study, expression of FasL mRNA was enhanced in the heart after reperfusion, and FasL immunoreactivity was predominantly localized in neutrophils, macrophages, $T$ cells, and vascular endothelial cells. Separate from its apoptotic activity, there is growing evidence that FasL has a strong proinflammatory activity. The forced expression of FasL in several cell types has been shown to induce an effusive neutrophil-mediated inflammatory response, as documented in vivo by either tissue transplant infiltration (Allison et al, 1997; Arai et al, 1997; Kang et al, 1997a, 1997b; Miwa et al, 1998; Seino et al, 1997) or neutrophil extravasation to the peritoneal cavity (Miwa et al, 1998). The neutrophil inflammatory response to membrane-bound FasL presented by tumor cells was blocked by the administration of anti-FasL antibody (Miwa et al, 1998). SFasL may be a direct chemoattractant for neutrophils. In vitro studies involving Boyden chamber migration assays suggested that the neutrophil response could be triggered by the establishment of sFasL chemoattractant gradient (Ottonello et al, 1999). Therefore, membrane-bound FasL and SFasL produced from these inflammatory cells may function as chemokines for neutrophils in the early stage of postreperfusion, and in this study, anti-FasL antibody neutralized this chemotactic activity, leading to a $41 \%$ decrease in neutrophil infiltration. Administration of anti-FasL antibody also achieved a $19 \%$ decrease in T cell infiltration and reduced IL-2 and IL-1 $\beta$ mRNA expression. FasL engagement by FasFc leads to the prevention of IL-2 secretion and cell death in FasL-expressing CD4 ${ }^{+} \mathrm{T}$ cells (Desbarats et al, 1998). Activated T cells produce IL-2 and mediate $T$ cell proliferation and differentiation in an autocrine fashion. Therefore, FasL engagement by antiFasL antibody may suppress IL-2 production from vanguard $T$ cells in the myocardium, leading to suppression of $T$ cell proliferation. In other conditions, FasL engagement suppresses T cell infiltration in the myocardium. For example, anti-FasL antibody reduced infiltration of inflammatory cells, including lymphocytes, macrophages, neutrophils, and giant cells, 

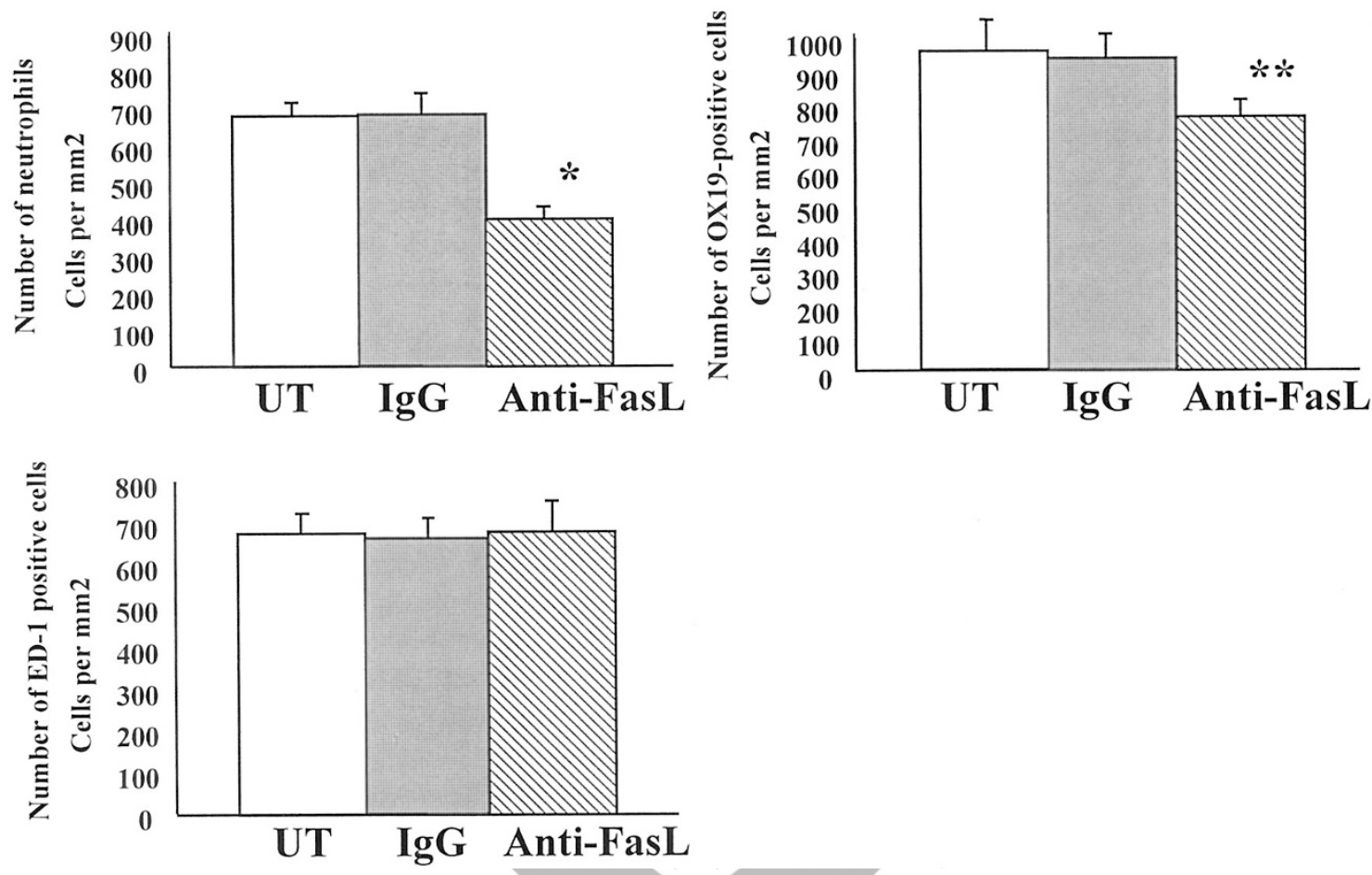

Figure 5 .

Effect of anti-FasL antibody on the number of infiltrating neutrophils, OX19-positive cells, and ED1-positive cells measured in the MI/R area 24 hours after reperfusion. The number of cells is expressed as the number per square millimeter. ${ }^{\star} p<0.05,{ }^{\star \star} p<0.0001$ versus untreated group and group treated with rabbit IgG.

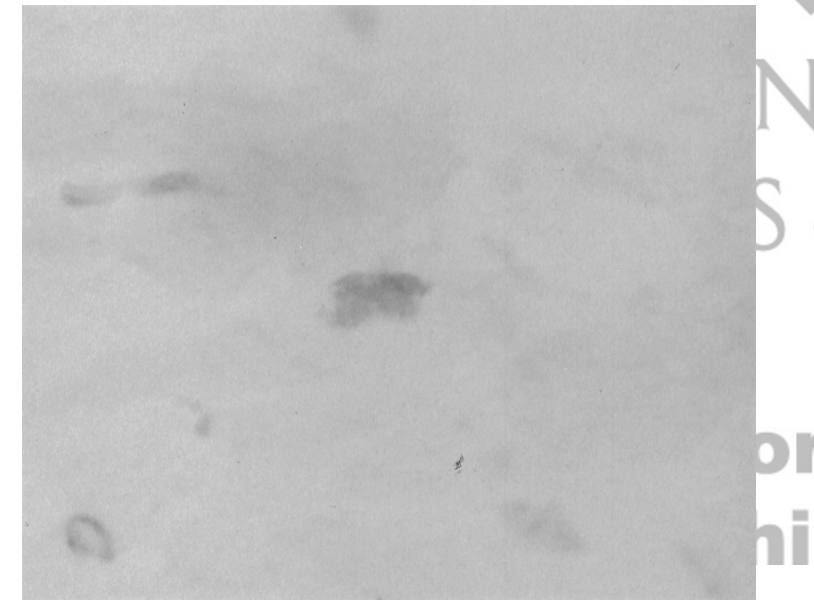

Figure 6.

Apoptosis was estimated with TUNEL staining (original magnification, $\times 640$ ). TUNEL-positive nuclei visualized with diaminobenzidine (brown) were detected in scattered myocytes stained with eosin.

in experimental autoimmune myocarditis mediated by CD4 ${ }^{+} \mathrm{T}$ cells (Ishiyama et al, 1998).

Attenuation of IL-1 $\beta$ and IL-2 expression may be associated with decreased numbers of inflammatory cells, because these cytokines are produced by several inflammatory cells, including macrophages (Herskowitz et al, 1995; Nathan, 1987), T cells (Salgame et al, 1991), and neutrophils (Lindemann et al, 1988). Cytokine mRNA expression, TNF- $\alpha$, IL-1 $\beta$, IL-2, IL-6, and IFN- $\gamma$, was observed in rats with MI/R injury (Herskowitz et al, 1995). However, among these cyto-

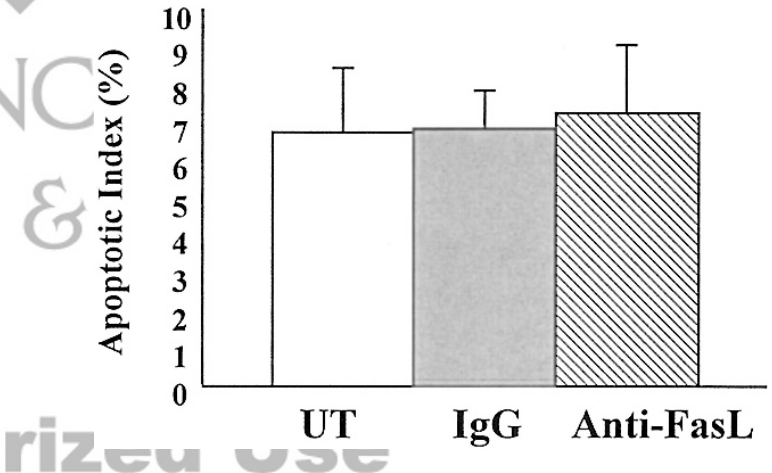

Figure 7.

Percentages of apoptotic myocytes detected by TUNEL. TUNEL-positive cardiomyocytes in untreated rats $(U T)$, and rats treated with rabbit $\lg G(I g G)$ and anti-FasL antibody (Anti-FasL).

kines, only IL-1 $\beta$ and IL-2 mRNA were reduced in this study. Therefore, FasL engagement may suppress $\mathrm{IL}-1 \beta$ and IL-2 production in inflammatory cells, as $\mathrm{IL}-2$ production from $\mathrm{CD} 4^{+} \mathrm{T}$ cells is suppressed by FasFc.

In our model, no significant difference in the number of ED1-positive macrophages was found between the anti-FasL antibody-treated group and the IgG-treated group. Therefore, other chemokines may mediate macrophage infiltration in the reperfused myocardium. Monocyte chemoattractant protein-1 (MCP-1) is an important mediator of monocyte recruitment to inflammatory sites (Robinson et al, 1989; Rollins et al, 1989). MCP-1 mRNA is consistently produced in the myo- 

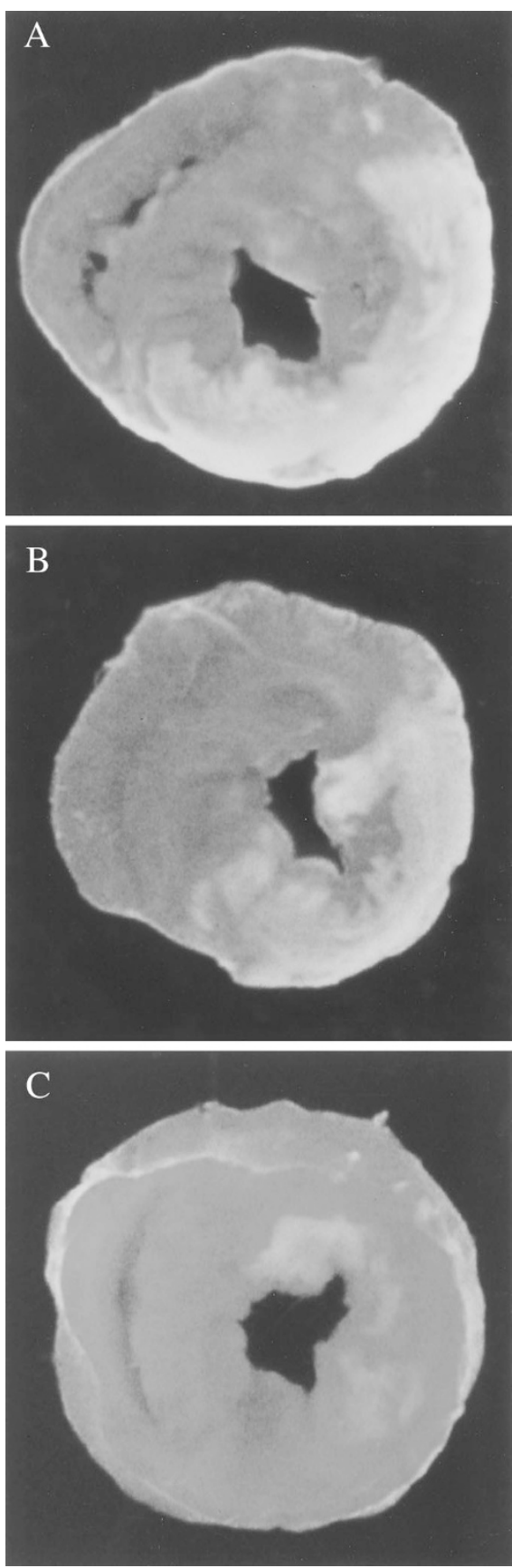

Figure 8.

Macroscopic view of the sliced heart after 30 minutes of ischemia and then by 24 hours of reperfusion. A, Infarcted heart without treatment. B, Infarcted heart treated with $\lg G$. C, Infarcted heart treated with anti-FasL antibody.

cardium, and its expression is augmented by $\mathrm{Ml} / \mathrm{R}$ (Ono et al, 1999). Anti-MCP-1 antibody decreased infiltration of macrophages and consequently reduced infarct size in $\mathrm{MI} / \mathrm{R}$ rats, indicating that $\mathrm{MCP}-1$ may play an important role in macrophage recruitment and myocyte injury in the reperfused myocardium.

Administration of anti-FasL antibody achieved a $46 \%$ decrease in the size of the infarct area. This effect of anti-FasL antibody was specific, because an equivalent dosage of normal rabbit IgG had no effect on the suppression of myocardial damage. Recent

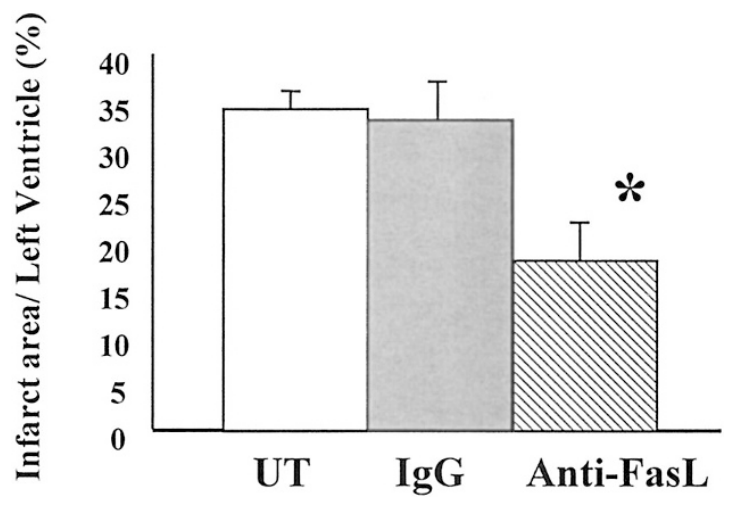

Figure 9.

Effect of anti-FasL antibody on myocardial infarct size as a percentage of the total left ventricular area $(n=8) .{ }^{* *} p<0.0001$ versus heart from untreated rats $(n=8)$ and rats treated with rabbit $\lg G(n=8)$.

studies have demonstrated that $\mathrm{I} / \mathrm{R}$ induces apoptosis in the reperfused myocardium, and this might be important for delayed cardiomyocyte death (Gottlieb et al, 1997). A caspase inhibitor attenuated apoptosis of cardiac myocytes, resulting in a decrease of infarct size (Yaoita et al, 1998). One of the main mechanisms of caspase activation has been shown to involve the release of cytochrome $\mathrm{c}$ from the mitochondria to the cytosol, and another important pathway is through a mitochondrion-independent mechanism that uses cell death receptors (eg, Fas and TNF receptor). SFasL is released by the postischemic hearts early after the onset of reperfusion, and isolated hearts from Fasdeficient mice display reduction in cell death after MI/R injury (Jeremias et al, 2000). Therefore, Fas might be directly involved in cell death after myocardial ischemia. In this study, we assessed apoptotic myocardial cell death with TUNEL staining, which is widely used to detect apoptosis in various tissues. The percentage of TUNEL-positive cardiomyocytes (the apoptotic index) of Group A, B, and C were $6.7 \pm 1.7 \%$, $6.8 \pm 1.0 \%$, and $7.2 \pm 1.8 \%$, respectively. There was no significant difference among the three groups. The results of this study suggest that the cardioprotective effect of anti-FasL antibody is due to its antiinflammatory action rather than antiapoptotic action in our model. Our results seem to contradict the study of Jeremias et al (2000) with regard to the contribution of apoptotic cell death. Therefore, further studies will be conducted to assess the cardioprotective effect of anti-FasL antibody in MI/R injury.

In conclusion, we have demonstrated that administration of anti-FasL antibody significantly reduces myocardial infarct size in a rat $\mathrm{MI} / \mathrm{R}$ model. This cardioprotective effect could be attributed to reduced neutrophils and T-lymphocyte accumulation and attenuation of cytokine secretion in the reperfused myocardium. These results suggest that FasL plays an important role in inflammatory states in the I/R injury. Anti-FasL antibody might represent a potential therapeutic agent for I/R injury, not only in the myocardium, but also in other organs. 


\section{Materials and Methods}

\section{Experimental Ischemia/Reperfusion Model}

This study was approved by the Animal Care Committee in accordance with Chiba University policies. Adult male Sprague-Dawley rats (250 to 300 g), purchased from Charles River Japan, Inc. (Kanagawa, Japan), were anesthetized with sodium pentobarbital $(30 \mathrm{mg} /$ $\mathrm{kg}$ ) by intraperitoneal injection. Rats were then intubated and ventilated with room air. Myocardial ischemia was produced by rapidly exteriorizing the heart and placing a 4.0 silk suture around the left coronary artery, approximately $2 \mathrm{~mm}$ from its origin. Ischemia was confirmed through elevation of the ST segment on an electrocardiogram and by change in the color of the myocardium. After 30 minutes of ischemia, the suture was removed, initiating reperfusion. The chest was then closed, pneumothorax was reduced by negative pressure, and the rats were returned to their cages.

\section{RT-PCR}

Total RNA was extracted from hearts of MI/R rats on 0 , 1,3 , and 24 hours after reperfusion and from shamoperated rats, using the Qiagen RNeasy MIDI kit (Qiagen, Hilden, Germany), and was used for firststrand CDNA synthesis with random hexamer oligonucleotides $\left(\mathrm{pd}(\mathrm{N})_{6}\right.$; Pharmacia P-L Biochemical, Milwaukee, Wisconsin) and M-MLV reverse transcriptase (Life Technologies, Gaithersburg, Maryland), according to a standard protocol. Two micrograms of CDNA reaction mixture was used as a template for $P C R$. IL-1 $\beta$, IL-2, II-6, TNF- $\alpha$, IFN- $\gamma$, FasL, and GAPDH mRNA were detected with primers and PCR conditions used previously (Damoiseaux et al, 1998; Herskowitz et al, 1995; Muschen et al, 1999).

The PCR reaction was carried out at three different cycle numbers to ensure it was performing in the linear range of amplification. RT-PCR products were electrophoretically separated on 3\% agarose gels and visualized by ethidium bromide staining under ultraviolet transillumination. Densitometric analysis of bands was performed using NIH Image 1.59 software program (National Institutes of Health, Bethesda, Maryland). Each band was normalized to the relevant GAPDH control.

\section{Antibody Treatment and Determination of Infarct Size}

Rats were randomly divided into three groups; Group A $(n=8)$, without treatment; Group B $(n=8)$, treated with nonspecific rabbit $\operatorname{lgG}(0.1 \mathrm{mg} / \mathrm{kg})$; and Group C $(n=8)$, treated with anti-FasL antibody $(0.1 \mathrm{mg} / \mathrm{kg}$; anti-P5, rabbit IgG) (Hakuno et al, 1996). Anti-FasL antibody or rabbit IgG was administered via the tail vein 1 hour before coronary artery occlusion. Twentyfour hours after reperfusion, rats were anesthetized with sodium pentobarbital $(30 \mathrm{mg} / \mathrm{kg}$, intraperitoneal injection), and the chest was reopened. The heart was excised, and the ventricle was cut into six transverse slices from the apex to the base. The slices were incubated for 10 minutes in 1\% triphenyltetrazolium chloride (TTC) solution at $37^{\circ} \mathrm{C}$. Regions that failed to demonstrate brick-red staining with 1\% TTC solution were considered to be infarcted myocardium. The slices were imaged by a color camera, and the images were stored on a Macintosh computer and analyzed by the NIH Image 1.59 software program. The results were expressed as the percentage of infarcted area to total left ventricular area. Heart tissues were fixed in $10 \%$ phosphate buffered formalin and embedded in paraffin for histologic studies.

\section{Leider Stain for Neutrophils}

Representative 4- $\mu \mathrm{m}$ thick paraffin-embedded sections were treated with the Leider stain using the naphthol AS-D chloroacetate esterase kit (Sigma, St. Louis, Missouri) in a standard manner to identify neutrophils in the I/R myocardium. The number of neutrophils in the I/R myocardium 24 hours after reperfusion was calculated from randomly selected fields, using CAS 200 (Becton Dickinson, San Jose, California). The resultant data were expressed as mean number \pm standard deviation per square millimeter.

\section{Immunohistochemistry}

Rat hearts were excised 24 hours after reperfusion. Freshly dissected left ventricles were frozen in optimal cutting temperature compound (OCT Compound; Miles Laboratories, Naperville, Illinois) in liquid nitrogen and stored at $-80^{\circ} \mathrm{C}$. Cryostat sections were cut sequentially at $4 \mu \mathrm{m}$ and fixed in acetone for 10 minutes. To identify the inflammatory cells, the slides were incubated with a mouse monoclonal antibody against OX6 (Serotec, Oxford, United Kingdom) for recognizing major histocompatibility complex (MHC) class II-expressing cells, including dendritic cells, some macrophages, and B lymphocytes; ED1 (PharMingen, San Diego, California), a marker for inflammatory macrophages; ED2 (BioSource International, Camarillo, California), a marker for resident macrophages; and OX19 (Serotec), a marker for pan-T cells (Ishiyama et al, 1997). After washing, the streptavidinbiotin complex method was performed according to a standard protocol for the Histfine kit from Nichirei Co. (Tokyo, Japan), and labeling was visualized with diaminobenzidine and hydrogen peroxide. The number of inflammatory cells was counted using a CAS 200 in the I/R myocardium and expressed as mean number \pm standard deviation per square millimeter. Double staining using rabbit anti-rat FasL antibody and ED1, ED2, OX6, or OX19 was performed using a modification of Nakane's method (Nakane, 1968). Cytokines were localized by the streptavidin-biotin complex method. The antibodies were removed from the sections by glycine-hydrochloric acid buffer, $\mathrm{pH} 2.2$, leaving the colored reaction product of diaminobenzidine. The second antigen was localized similarly, using the Fast Blue Kit (Nichirei) that develops reaction products of a color different from diaminobenzidine. 


\section{TUNEL Assay}

The TUNEL assay was performed using the ApopTag Kit (Oncor, Gaithersburg, Maryland). In brief, cryostat sections were fixed in $1 \%$ paraformaldehyde and permeabilized with the solvent (ethanol:acetic acid, 2:1) for 5 minutes at $-20^{\circ} \mathrm{C}$. Endogenous peroxidase was inactivated by incubation with $3 \% \mathrm{H}_{2} \mathrm{O}_{2}$. Terminal deoxynucleotidyltransferase and digoxigenin-11dUTP were added to the sections according to the instructions provided by the manufacturer. The incorporated nucleotides were optimized for antidigoxigenin antibody binding. Nuclei were counterstained with hematoxylin. The sections were then stained with eosin to identify myocytes. Normal rat testis was used as the control tissue. The percentages of TUNELpositive nuclei of cardiomyocytes (apoptotic index) were calculated by counting 500 nuclei of myocytes at a high magnification $(\times 1,000)$ per tissue per rat 3 hours after reperfusion.

\section{Statistical Analysis}

Data were expressed as mean \pm standard deviation. The values were tested by one-way ANOVA, and then by Scheffé's multiple comparison test. In all analyses, findings of $p<0.05$ were considered statistically significant.

\section{References}

Allison J, Georgiou HM, Strasser A, and Vaux DL (1997). Transgenic expression of CD95 ligand on islet $\beta$ cells induces a granulocytic infiltration but does not confer immune privilege upon islet allografts. Proc Natl Ačad Sci USA 94:39433947.

Arai H, Gordon D, Nabel EG, and Nabel GJ (1997). Gene transfer of Fas ligand induces tumor regression in vivo. Proc Natl Acad Sci USA 94:13862-13867.

Birdsall HH, Green DM, Trial J, Youker KA, Burns AR, MacKay CR, LaRosa GJ, Hawkins HK, Smith CW, Michael LH, Entman ML, and Rossen RD (1997). Complement C5a, TGF- $\beta 1$, and MCP-1, in sequence, induce migration of monocytes into ischemic canine myocardium within the first one to five hours after reperfusion. Circulation 95:684-692.

Braunwald E and Kloner RA (1985). Myocardial reperfusion: A double-edged sword? J Clin Invest 76:1713-1719.

Damoiseaux JG, Theunissen R, Broeren CP, van Breda Vriesman PJ, and Duijvestijin AM (1998). Comparison of detection techniques for cytokine reverse transcriptase polymerase chain reaction; digoxigenin-labeled polymerase chain reaction permits sensitive detection of cytokine mRNA in rat heart allografts. J Immunol Methods 217:185-193.

Desbarats J, Duke RC, and Newell MK (1998). Newly discovered role for Fas ligand in the cell-cycle arrest of $\mathrm{CD}^{+}{ }^{+} \mathrm{T}$ cells. Nat Med 4:1377-1382.

Dreyer WJ, Michael LH, West MS, Smith CW, Rothlein R, Rossen RD, Anderson DC, and Entman ML (1991). Neutrophil accumulation in ischemic canine myocardium. Insights into time course, distribution, and mechanism of localization during early reperfusion. Circulation 84:400-411.
Finkel MS, Oddis CV, Jacob TD, Watkins SC, Hattler BG, and Simmons RL (1992). Negative inotropic effects of cytokines on the heart mediated by nitric oxide. Science 257:387-389.

Gottlieb RA, Burleson KO, Kloner RA, Babior BM, and Engler $\mathrm{RL}$ (1997). Reperfusion injury induces apoptosis in rabbit cardiomyocytes. J Clin Invest 100:1363-1372.

Hakuno N, Koji T, Yano T, Kobayashi N, Tsutsumi O, Taketani Y, and Nakane PK (1996). Fas/APO-1/CD95 system as a mediator of granulosa cell apoptosis in ovarian follicle atresia. Endocrinology 137:1938-1948.

Herskowitz A, Choi S, Ansari AA, and Wesselingh S (1995). Cytokine mRNA expression in postischemic/reperfused myocardium. Am J Pathol 146:419-428.

Ishiyama S, Hiroe M, Nishikawa S, Abe S, Shimojo T, Ito H, Ozasa S, Yamakawa K, Matsuzaki M, Mohammed MU, Nakazawa H, Kasajima T, and Marumo F (1997). Nitric oxide contributes to the progression of myocardial damage in experimental autoimmune myocarditis in rats. Circulation 95:489-496.

Ishiyama S, Hiroe M, Nishikawa T, Shimojo T, Abe S, Fujisaki $\mathrm{H}$, Ito $\mathrm{H}$, Yamakawa $\mathrm{K}$, Kobayashi $\mathrm{N}$, Kasajima $\mathrm{T}$, and Marumo $F$ (1998). The Fas/Fas ligand system is involved in the pathogenesis of autoimmune myocarditis in rats. $\mathrm{J} \mathrm{Im-}$ munol 161:4695-4701.

Jeremias I, Kupatt C, Martin-Villalba A, Habazettl H, Schenkel $J$, Boekstegers $P$, and Debatin KM (2000). Involvement of CD95/Apo1/Fas in cell death after myocardial ischemia. Circulation 102:915-920.

Kang SM, Hofmann A, Le D, Springer ML, Stock PG, and Blau HM (1997a). Immune response and myoblasts that express Fas ligand. Science 278:1322-1324.

Kang SM, Schneider DB, Lin Z, Hanahan D, Dichen DA, Stock PG, and Baekkeskov S (1997b). Fas ligand expression in islets of Langerhans does not confer immune privilege and instead targets them for rapid destruction. Nat Med 3:738743.

Kiener PA, Davis PM, Rankin BM, Klebanoff SJ, Ledbetter JA Starling GC, and Liles WC (1997). Human monocytic cells contain high levels of intracellular Fas ligand. Rapid release following cellular activation. J Immunol 159:1594-1598.

Liles WC, Kiener PA, Ledbetter JA, Aruffo A, and Klebanoff SJ (1996). Differential expression of Fas (CD95) and Fas ligand on normal human phagocytes: Implications for the regulation of apoptosis in neutrophils. J Exp Med 184:429440.

Lindemann A, Riedel D, Oster W, Meuer SC, Blohm D, Mertelsmann RH, and Herrmann F (1988). Granulocyte/ macrophage colony-stimulating factor induces interleukin 1 production by human polymorphonuclear neutrophils. J Immunol 140:837-839.

Mehta JL, Nichols WW, and Mehta P (1988). Neutrophils as potential participants in acute myocardial ischemia: Relevance to reperfusion. J Am Coll Cardiol 11:1309-1316.

Miwa K, Asano M, Horai R, Iwakura Y, Nagata S, and Suda T (1998). Caspase 1-independent IL-1 $\beta$ release and inflammation induced by the apoptosis inducer Fas ligand. Nat Med 4:1287-1292.

Muschen M, Warskulat U, Peters-Regehr T, Bode JG, Kubitz R, and Häussinger D (1999). Involvement of CD95 (Apo-1/ Fas) ligand expressed by rat Kupffer cells in hepatic immunoregulation. Gastroenterology 116:666-677. 
Nagata S (1994). Fas and Fas ligand: A death factor and its receptor. Adv Immunol 57:129-144.

Nagata S and Golstein P (1995). The fas death factor. Science 267:1449-1456.

Nakane PK (1968). Simultaneous localization of multiple tissue antigens using the peroxidase-labeled antibody method: A study of pituitary glands of rat. J Histochem Cytochem 16:557-560.

Nathan CF (1987). Secretory products of macrophages. J Clin Invest 79:319-326.

Ono K, Matsumori A, Furukawa $\mathrm{Y}$, Igata $\mathrm{H}$, Shioi T, Matsushima K, and Sasayama S (1999). Prevention of myocardial reperfusion injury in rats by an antibody against monocyte chemotactic and activating factor/monocyte chemoattractant protein-1. Lab Invest 79:195-203.

Ottonello L, Tortolina G, Amelotti M, and Dallegri F (1999). Soluble Fas ligand is chemotactic for human neutrophilic polymorphonuclear leukocytes. J Immunol 162:3601-3606.

Robinson EA, Yoshimura T, Leonard EJ, Tanaka S, Griffin PR, Shabanowitz J, Hunt DF, and Appella E (1989). Complete amino acid sequence of a human monocyte chemoattractant, a putative mediator of cellular immune reactions. Proc Natl Acad Sci USA 86:1850-1854.

Rollins BJ, Stier P, Ernst T, and Wong GG (1989). The human homolog of the JE gene encodes a monocyte secretory protein. Mol Cell Biol 9:4687-4695.
Salgame P, Abrams JS, Clayberger C, Goldstein H, Convit J, Modlin RL, and Bloom BR (1991). Differing lymphokine profiles of functional subsets of human CD4 and CD8 T cell clones. Science 254:279-282.

Seino K, Kayagaki N, Okumura K, and Yagita H (1997). Antitumor effect of locally produced CD95 ligand. Nat Med 3:165-170.

Suda T, Takahashi T, Golstein P, and Nagata S (1993). Molecular cloning and expression of the Fas ligand, a novel member of the tumor necrosis factor family. Cell 75:11691178.

Yaoita H, Ogawa K, Maehara K, and Maruyama Y (1998). Attenuation of ischemia/reperfusion injury in rats by a caspase inhibitor. Circulation 97:276-281.

Yue P, Massie BM, Simpson PC, and Long CS (1998). Cytokine expression increases in nonmyocytes from rats with postinfarction heart failure. Am J Physiol 275:H250-H258.

Zwacka RM, Zhang Y, Halldorson J, Schlossberg H, Dudus L, and Engelhardt JF (1997). CD4 ${ }^{+}$T-lymphocytes mediate ischemia/reperfusion-induced inflammatory responses in mouse liver. J Clin Invest 100:279-289.

\section{LIPPINCOTT \\ WILLIAMS \& WILKINS}

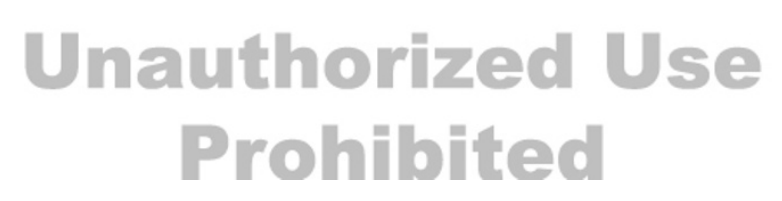

